\title{
Pemanfaatan Selulosa dari Rumput Gajah (Pennisetum purpureum) pada Sintesis Karboksimetil Selulosa (CMC)
}

\section{[Utilization of Cellulose from Pennisetum purpureum at The Synthesis of Carboxy Methyl Cellulose (CMC)]}

\author{
Erwin Abd Rahim*, Grace Sita Turumi, Syaiful Bahri, Jusman, Syamsuddin \\ Jurusan Kimia Fakultas MIPA Universitas Tadulako, Jalan Soekarno-Hatta Km. 9, Palu, Indonesia
}

\begin{abstract}
Cellulose from Pennisetum purpureum has been used as the main ingredient in the synthesis of carboxymethyl cellulose (CMC). The purpose of $\mathrm{CMC}$ synthesis from the cellulose of Pennisetum purpureum is to obtain CMC compounds with the best degree of substitution (DS) value and the highest yield. The study was conducted using a completely randomized design with a factorial pattern consisting of two independent variables, namely the concentration of trichloroacetic acid (10\%, 20\%, and 30\%) and reaction time (3 and 4 hours). The results showed that the CMC with the highest DS value $(0.839)$ was obtained using $20 \%$ trichloroacetic acid with a reaction time of 3 hours. The highest CMC yield was $30.15 \%$ which was obtained using $30 \%$ trichloroacetic acid with a reaction time of 4 hours.
\end{abstract}

Keywords: Pennisetum purpureum, carboxymethyl cellulose, substitution degree.

Abstrak. Selulosa dari rumput gajah telah digunakan sebagai bahan utama pada sintesis karboksimetil selulosa (CMC). Tujuan sintesis CMC dari selulosa rumput gajah adalah untuk mendapatkan senyawa CMC dengan nilai derajat subtitusi (DS) terbaik dan rendemen tertinggi. Penelitian dilakukan menggunakan rancangan acak lengkap pola faktorial yang terdiri dari dua variabel bebas, yaitu konsentrasi asam trikloroasetat $(10 \%, 20 \%$, dan $30 \%)$ dan waktu reaksi (3 dan 4 jam). Hasil penelitian menunjukkan bahwa CMC dengan nilai DS tertinggi $(0,839)$ diperoleh pada penggunaan asam trikloroasetat $20 \%$ dengan waktu reaksi 3 jam. Rendemen CMC tertinggi adalah $30,15 \%$ yang diperoleh pada penggunaan asam trikloroasetat $30 \%$ dengan waktu reaksi 4 jam.

Kata kunci: Rumput gajah, karboksimetil selulosa, derajat subtitusi.

Diterima: 7 November 2019, Disetujui: 22 Agustus 2021

Sitasi: Rahim, E A., Turumi, G S., Bahri, S., Jusman., dan Syamsuddin. (2021). Pemanfaatan Selulosa dari Rumput Gajah (Pennisetum purpureum) pada Sintesis Karboksimetil Selulosa (CMC). KOVALEN: Jurnal Riset Kimia, 7(2): 146-153.

\section{LATAR BELAKANG}

\section{Carboxymethyl cellulose (CMC)} merupakan salah satu senyawa hasil dari modifikasi selulosa (Wijayani et al., 2005). CMC banyak digunakan pada industri makanan untuk memperbaiki tekstur produk makanan.

\footnotetext{
* Corresponding author

E-mail: erwin_abdulrahim@yahoo.com
}

Senyawa CMC memiliki fungsi stabilisator, pengental, pengemulsi dan pembentuk gel (Winarno, 1985). Kemampuan CMC dalam mengikat molekul air menyebabkan molekulmolekul air mudah terjebak di dalam struktur gel CMC, sehingga kualitas tekstur produk makanan tetap terjaga (Minifie, 1989).

Selulosa merupakan senyawa dasar yang digunakan untuk pembuatan CMC. Selulosa 
yang terdapat pada tumbuhan biasanya berada dalam bentuk terikat dengan senyawa lain seperti selulosa maupun lignin (Martina et al., 2002). Selulosa tersebut dapat dipisahkan dari ligninnya dengan cara delignifikasi menggunakan $\mathrm{NaOH}$. Dalam proses delignifikasi ini sekaligus juga dapat melepaskan ikatan hemiselulosa (Saleh et al., 2009). Salah satu jenis tanaman yang tinggi kandungan selulosanya adalah rumput gajah.

Rumput gajah (Pennisetum puroureum) adalah tanaman yang tumbuh pada daerah yang memiliki kandungan nutrisi terbatas. Kondisi tanah yang rusak akibat erosi dapat diperbaiki oleh tanaman ini. Dan juga dapat tumbuh pada tanah kritis (Sanderson \& Adler, 2008). Berdasarkan hasil penelitian yang dilakukan oleh (Nasution et al., 2016), rumput gajah mengandung serat kasar $34,2 \%$, protein kasar 10,2\%, lemak 1,6\% abu $11,7 \%$. Berdasarkan kondisi tersebut, maka rumput gajah berpotensi dimanfaatkan sebagai sumber selulosa pada sintesis CMC.

Karakteristik CMC dipengaruhi oleh yang proses alkalisasi dan karboksimetilasi. Alkalisasi umumnya menggunakan basa, seperti $\mathrm{NaOH}$ untuk mengaktifkan gugus-gugus hidroksil $(-\mathrm{OH})$ pada molekul glukosa yang selanjutnya digunakan sebagai inisiasi untuk mempermudah reaksi karboksimetilasi. Karboksimetilasi menggunakan monokloroasetat baik dalam bentuk asam maupun garamnya. Semakin bertambah kadar basa yang digunakan, maka dapat mempercepat reaksi gugus -OH selulosa dengan monokloroasetat (Wijayani et al., 2005).

Kualitas CMC yang dihasilkan dari ekstrak selulosa ditentukan dari derajat subtitusi molekul selulosa. Derajat subtitusi (DS) sangat menentukan kelarutan CMC dalam air. Jika DS $<0,3$, maka CMC larut dalam larutan alkali, sedangkan CMC mudah larut dalam air jika nilai $D S \geq 0,4$ (Setiawan dalam Wijayani et al., 2005). Sumber selulosa yang dapat dimanfaatkan pada sintesis CMC sangat melimpah di alam. Tumbuhan jenis rumput-rumputan adalah salah satu sumber selulosa yang sangat mudah ditemui, seperti rumput gajah.

\section{METODE PENELITIAN}

\section{Bahan dan Peralatan}

Bahan utama yang digunakan meliputi rumput gajah, natrium hidroksida, dan asam trikloroasetat. Peralatan yang digunakan adalah neraca digital Kern $440-43 N$, oven analitik Memmert, termometer, pengaduk magnetik, ayakan 60 mesh, dan Spektrofotomer FT-IR.

\section{Prosedur Penelitian}

\section{Pembuatan tepung rumput gajah}

Rumput gajah sebelum digunakan di potong-potong, kemudian dijemur sampai kering. Sampel yang telah kering diserbukkan dan diayak dengan ukuran 60 mesh. Tepung rumput gajah dikeringkan kembali dalam oven pada suhu $60^{\circ} \mathrm{C}$ oven selama 1 jam. Sampel tepung yang telah kering ditentukan kadar airnya secara gravimetri (Wijayani et al., 2005).

\section{Ekstraksi selulosa rumput gajah (Bidin, 2010)}

Tepung rumput gajah direndam dan didiamkan selama 24 jam di dalam larutan $\mathrm{NaOH} 10 \%$ dengan perbandingan 1:10 (b/v). Hasil rendaman disaring dan residu direndam dalam larutan Na-hipoklorit 5\% selama 3 jam. Hasil rendaman kembali disaring dan aroma hipoklorit dihilangkan dari residu serta $\mathrm{pH}$ dinetralkan dengan cara dicuci dengan akuades panas. Residu dikeringkan di dalam 
oven pada suhu $60{ }^{\circ} \mathrm{C}$ hingga massa residu konstan dan ditentukan rendemen selulosa kasar (Persamaan 1).

Rendemen selulosa $(\%)=\frac{m_{s}}{m_{r g}} \times 100$

Keterangan:

$\mathrm{m}_{\mathrm{s}}=$ massa selulosa

$\mathrm{m}_{\mathrm{rg}}=$ massa serbuk rumput gajah

\section{Pembuatan CMC}

Selulosa rumput gajah ditimbang $5 \mathrm{~g}$ dan dicampurkan ke dalam $100 \mathrm{~mL}$ akuades. Reaksi alkalisasi dilakukan dengan penambahan sedikit demi sedikit $10 \mathrm{~mL} \mathrm{NaOH}$ $30 \%$ sambil diaduk selama 1 jam. Dilakukan proses karboksimetilasi melalui penambahan asam trikloroasetat dengan konsentrasi 10, 20, dan $30 \%$ pada suhu $55^{\circ} \mathrm{C}$ selama 3 dan 4 jam. Larutan hasil karboksimetilasi dinetralkan menggunakan asam asetat glasial dan disaring. Residu direndam dalam $100 \mathrm{~mL}$ metanol selama 24 jam dan disaring kembali. CMC yang diperoleh dikeringkan dalam oven 60 'C (Nur'ain et al., 2017), selanjutnya ditentukan rendemennya (Persmaan 2):

Rendemen CMC (\%) $=\frac{m_{\mathrm{cmc}}}{m_{\mathrm{s}}} \times 100$

Keterangan:

$\mathrm{m}_{\mathrm{s}}=$ massa selulosa

$\mathrm{M}_{\mathrm{cmc}}=$ massa $\mathrm{CMC}$

\section{Penentuan derajat subtitusi CMC}

CMC ditimbang $2 \mathrm{~g}$ dan ditambahkan ke dalam $60 \mathrm{~mL}$ larutan etanol 95\%, selanjutnya ditambahkan dengan $10 \mathrm{~mL}$ larutan $\mathrm{NaNO}_{3} 2 \mathrm{M}$ dan diaduk selama 2 menit, kemudian dipanaskan selama 5 menit dan diaduk selama 15 menit. Campuran hasil reaksi disaring dan residu dicuci dengan etanol $95 \%$ yang telah dipanaskan pada suhu $60 \stackrel{\circ}{\circ}$. Residu dicuci kembali dengan metanol dan dikeringkan di dalam oven pada suhu $105^{\circ} \mathrm{C}$ selama 3 jam. Residu kering ditimbang 0,5 g dan dicampurkan dengan $100 \mathrm{~mL}$ aquadest dalam erlenmeyer, kemudian ditambahkan $25 \mathrm{~mL}$ larutan $\mathrm{NaOH}$ 0,5 N, selanjutnya dipanaskan selama 15 menit. Campuran yang panas ditambahkan indikator pp, kemudian dititrasi dengan $\mathrm{HCl}$ 0,3 $\mathrm{N}$ (Elomaa et al., 2004). Derajat subtitusi ditentukan dengan Persamaan 4.

$$
\begin{aligned}
& \text { \% CMC }=\left[\left(\mathrm{V}_{0}-\mathrm{V}_{\mathrm{n}}\right) \times 0,058 \times 100\right] / \mathrm{M} \\
& \mathrm{DS}=[162 \times \% \mathrm{CMC} /[5800-(57 \times \% \mathrm{CMC})] \\
& \text { Keterangan: } \\
& \mathrm{DS}=\text { Derajat subtitusi } \\
& \mathrm{V}_{0}=\text { volume } \mathrm{HCl} \text { untuk menitrasi blanko }(\mathrm{mL}) \\
& \mathrm{V}_{\mathrm{n}}=\text { volume } \mathrm{HCl} \text { untuk menitrasi sampel }(\mathrm{mL}) \\
& \mathrm{M}=\text { Massa sampel }(\mathrm{gram})
\end{aligned}
$$

\section{HASIL DAN PEMBAHASAN}

\section{Ekstrak Selulosa Rumput Gajah}

Proses delignifikasi bertujuan agar senyawa selulosa yang terdapat dalam bahan terbebas dari komponen-komponen lainnya sehingga dalam proses karboksimetil menghasilkan derajat subtitusi yang cukup tinggi. Untuk menghilangkan komponenkomponen lain yang terdapat pada ekstrak selulosa dilakukan pembilasan selulosa dengan air sampai $\mathrm{pH}$ mendekati $\mathrm{pH} 7$; ini dibuktikan dengan mengukur $\mathrm{pH}$ dari air cucian sampai diperoleh pH 6,5. Pencucian dilakukan dengan tujuan untuk menghilangkan sisa-sisa $\mathrm{NaOH}$ lignin yang ada pada ekstrak seulosa kasar dimana terjadi perubahan endapan dari berwarna coklat menjadi putih kekuningan.

Ekstrak selulosa yang telah melalui proses bleaching dengan larutan hipoklorit didapatkan serbuk berwarna putih kekuningan. Menurut Wagiyanto (2009), natrium hipoklorit juga dapat berperan sebagai reagen untuk delignifikasi tanpa mengurangi serat selulosa secara signifikan. Hipoklorit pada proses bleaching 
dihilangkan dengan penambahan air panas termasuk hemiselulosa (Wagiyanto, 2009) .

Hasil dari proses delignifikasi pada serbuk rumput gajah ini diperoleh selulosa kasar dengan rendemen $37,98 \%$. Nur'ain et al., (2017) telah menggunakan metode yang sama dengan penelitian ini untuk mengekstrak selulosa batang jagung dan memperoleh rendemen ekstrak selulosa yaitu $36,43 \%$.

\section{Karboksimetil Selulosa dari Rumput Gajah}

Pada penelitian ini proses alkalisasi menggunakan larutan $\mathrm{NaOH}$ yang berfungsi untuk mengaktifkan gugus-gugus hidroksil ($\mathrm{OH})$ pada selulosa. Jika aktivasi selulosa berjalan sempurna, maka proses karboksimetilasi juga akan sempurna. Bila konsentrasi $\mathrm{NaOH}<30 \%$ pada proses alkalisasi akan menyebabkan alkalisasi tidak berjalan sempurna karena banyak gugus $-\mathrm{OH}$ pada selulosa yang tidak teraktivasi, sehingga CMC yang dihasilkan menjadi sedikit dan nilai DS rendah (Agustriono \& Hasanah, 2016).

Dalam proses alkalisasi terjadi perubahan warna secara perlahan-lahan dari selulosa putih kekuningan menjadi berwarna coklat. Jumlah penambahan $\mathrm{NaOH}$ yang semakin banyak dapat menyebabkan campuran mengalami perubahan warna menjadi semakin pekat. Perubahan warna terjadi karena adanya reaksi $\mathrm{NaOH}$ dengan sisa-sisa lignin yang masih terdapat dalam ekstrak selulosa (Nur'ain et al., 2017). Kemudian pada tahap karboksimetilasi pada waktu penambahan asam trikloroasetat terjadi perubahan warna dari coklat tua menjadi kekuningan. CMC yang diperoleh berwarna putih akibat adanya penambahan asam asetat glasial pada saat penetralan dan perendaman dengan etanol sehingga pengotor akan dihilangkan dari produk CMC.

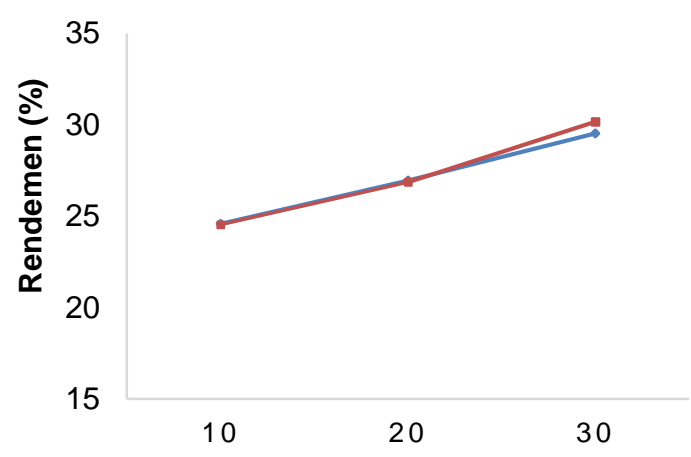

Konsentrasi Asam Trikloroasetat (\%)

$\longrightarrow$ waktu reaksi 3 jam $\longrightarrow$ waktu reaksi 4 jam

Gambar 1. Rendemen CMC berdasarkan konsentrasi asam trikloroasetat

Rendemen tertinggi CMC terdapat pada konsentrasi asam trikloroasetat $30 \%$, yaitu $30,15 \%$ dan rendemen terrendah terdapat pada penambahan konsentrasi asam trikloroasetat $10 \%$ yaitu $24,54 \%$ (Gambar 1 ). Hasil ini belum diperoleh kondisi optimal karena grafik rendemen masih menunjukkan kecenderungan peningkatan. Nilai rendemen antara waktu reaksi 3 dan 4 jam juga belum terlihat berbeda signifikan karena rekasi antara selulosa dan trikloroasetat belum optimal, sehingga dimungkin adanya penambahan waktu reaksi pada penelitian berikutnya. Hasil hampir serupa didapatkan juga oleh Safitri et al., (2017) yang mensintesis CMC dari selulosa kulit durian pada waktu reaksi 4 jam dengan rendemen $39,77 \%$.

Hasil CMC yang diperoleh lebih kecil dibandingkan proses pembuatan CMC yang dilakukan oleh Bidin (2010) yaitu sebesar 67,52\% dan Melisa (2014) sebesar 69,73\%. Kedua peneliti ini dalam pembuatan CMC menggunakan senyawa monokloroasetat dimana senyawa ini lebih reaktif bila dibandingkan dengan trikloroasetat. Akibatnya rendemen CMC yang dihasilkan menggunakan trikloroasetat menjadi lebih rendah. Rendahnya 
rendemen $\mathrm{CMC}$ yang dihasilkan kemungkinan juga disebabkan oleh tingkat kemurnian dari ekstrak selulosa yang digunakan sebagai bahan dasar pembuatan CMC.

\section{Nilai Derajat Subtitusi (DS) CMC}

Hasil analisis nilai DS menunjukkan bahwa pada penambahan asam trikloroasetat $20 \%$ terjadi peningkatan nilai DS hingga 0,839 dan setelah itu, nilai DS kembali turun menjadi 0,634 (Gambar 2). Kondisi yang sama terjadi pada nilai DS pada waktu reaksi 4 jam. Berdasarkan penelitian ini kondisi terbaik terhadap kualitas dari CMC adalah pada penambahan asam trikloroasetat $20 \%$. Waktu reaksi 3 jam memiliki nilai DS yang lebih tinggi dibandingkan waktu reaksi 4 jam. Hal tersebut terjadi karena waktu reaksi yang semakin lama menyebabkan struktur karboksimetil selulosa mengembang saat proses alkilasi, sehingga jarak antar gugus semakin melebar dan ikatan semakin lemah hingga putus, akhirnya proses subtitusi tidak terjadi (Silsia, 2018; Nisa \& Putri, 2014).

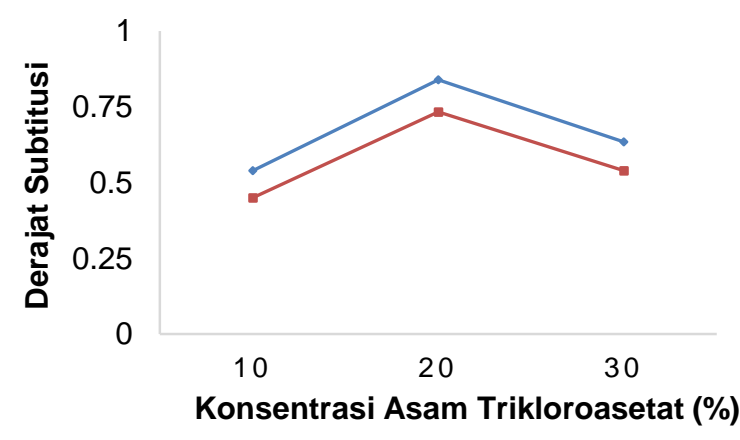

$\longrightarrow$ waktu reaksi 3 jam $\longrightarrow$ waktu reaksi 4 jam

Gambar 2. Nilai derajat subtitusi CMC

Derajat subsitusi tertinggi terjadi pada penggunaan konsentrasi asam trikloroasetat $20 \%$ dan waktu reaksi 3 jam (Gambar 2). Hasil yang diperoleh lebih tinggi dibandingkan nilai DS CMC dari selulosa kulit buah kakao yang menggunakan trikloroasetat $20 \%$ dan waktu reaksi 3 jam yang bernilai sekitar 0,15 (Nisa \& Putri, 2014). Sementara itu, Sebayang \& Sembiring, 2017 menggunakan selulosa dari tanaman palem-paleman untuk sintesis CMC, mendapatkan nilai DS yang hampir sama dengan penelitian yang dilakukan, yaitu 0,82 . Pada penelitian lainnya, CMC dari pelepah sawit memiliki nilai derajat subsitusi yang lebih kecil, yaitu 0,75 (Ferdiansyah et al., 2017). Nilai DS CMC yang diperoleh telah sesuai dengan Standar Nasional Indonesia (SNI) dan FAO. Nilai DS dalam SNI berada pada mutu 1 jika berkisar 0,7 - 1,2 (Nur'ain et al., 2017), sedangkan nilai DS dalam standarisasi FAO adalah antara 0,2-1,5 (Ferdiansyah et al., 2017).

\section{Spektrum FTIR Senyawa CMC dari Rumput Gajah}

Spektrum FTIR menunjukkan gugus fungsional dari senyawa CMC yang dihasilkan dari selulosa rumput gajah. Spektrum FTIR CMC dari rumput gajah pada Gambar 3 menunjukkan adanya peak pada bilangan gelombang $3425 \mathrm{~cm}^{-1}$ yang merupakan gugus $\mathrm{OH}$ dari cincin glukopiranosa pada CMC. Adanya broad peak pada bilangan gelombang $3700-3100 \mathrm{~cm}^{-1}$ menunjukkan adanya gugus $\mathrm{OH}$ yang memiliki ikatan hidrogen dengan gugus - $\mathrm{OH}$ lain dari monomer glukosa (Eriningsih et al., 2011; Saputrayadi et al., 2018).

Spektrum IR penciri dari CMC terdapat pada gugus $-\mathrm{CH}_{2}$ pada bilangan gelombang $1419 \mathrm{~cm}^{-1}$ dan terdapat gugus $-\mathrm{C}=\mathrm{O}$ (karbonil) pada bilangan gelombang $1635 \mathrm{~cm}^{-1}$. Kedua peak yang didapatkan ini telah sesuai dengan spektrum IR dari CMC komersial (Tabel 1). Lestari et al. (2013), juga melaporkan bahwa CMC dari limbah tanaman jagung memiliki gugus $-\mathrm{OH}$ pada panjang bilangan gelombang 
$1604 \mathrm{~cm}^{-1}$ dan- $\mathrm{CH}_{2}$ pada bilangan gelombang

$1419 \mathrm{~cm}^{-1}$.

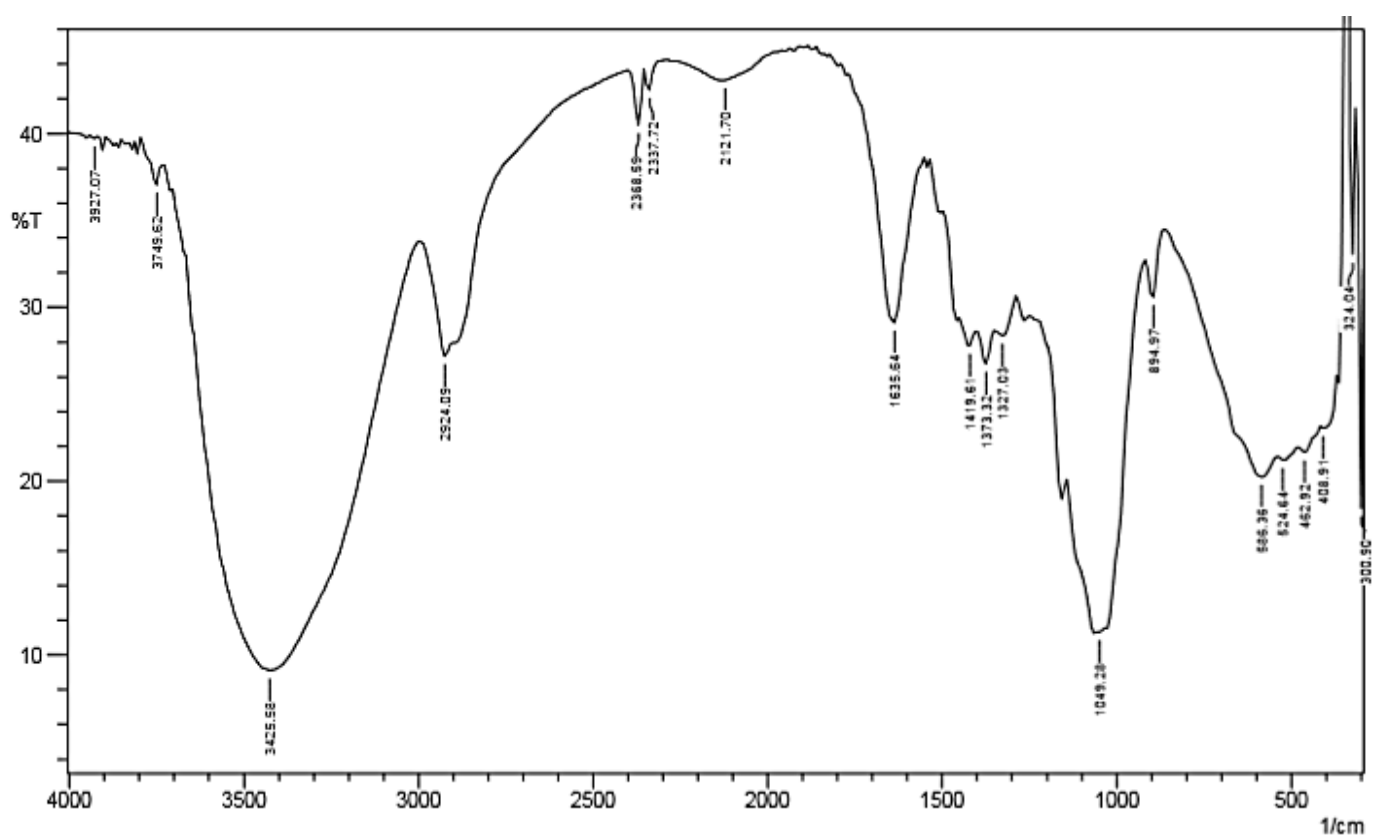

Gambar 3. Spektrum FTIR Karboksimetil Selulosa dari selulosa rumput gajah

Tabel 1. Perbandingan spektrum FTIR CMC Komersial dengan $\mathrm{CMC}$ rumput gajah

\begin{tabular}{|c|c|c|c|}
\hline No & $\begin{array}{r}\text { Bilangan G } \\
(\mathrm{cm}\end{array}$ & $\begin{array}{l}\text { lombang } \\
1)\end{array}$ & \\
\hline & $\begin{array}{c}\text { CMC } \\
\text { Komersial }\end{array}$ & $\begin{array}{l}\text { CMC } \\
\text { Rumput } \\
\text { Gajah }\end{array}$ & Gugus Fungsi \\
\hline 1. & 3433 & 3425 & -OH stretching \\
\hline 2. & 2916 & 2924 & $\begin{array}{l}-\mathrm{CH} \text { stretching } \\
\mathrm{CH}_{2} \& \quad \mathrm{CH}_{3} \\
\text { grup }\end{array}$ \\
\hline 3. & 1604 & 1635 & $\begin{array}{l}-\mathrm{C}=\mathrm{O} \text { region } \\
\text { (Konstituen } \\
\mathrm{CMC} \text { ) }\end{array}$ \\
\hline 4. & 1419 & 1419 & $\begin{array}{l}-\mathrm{CH}_{2} \\
\text { scissoring } \\
\text { (Konstiturn } \\
\text { CMC) }\end{array}$ \\
\hline 5. & 1327 & 1327 & -OH bending \\
\hline 6. & 1095 & 1049 & $\begin{array}{l}\text {-C-O-C } \\
\text { asymmetry } \\
\text { bridge } \\
\text { stretching }\end{array}$ \\
\hline 7. & 902 & 894 & $\begin{array}{l}-1,4-\beta \\
\text { glikosidik }\end{array}$ \\
\hline
\end{tabular}

Peak yang tajam pada bilangan gelombang $1049 \mathrm{~cm}^{-1}$ menunjukkan adanya gugus $\mathrm{C}-\mathrm{O}-\mathrm{C}$ yang merupakan ikatan glikosidik antar monomer glukosa yang diperkuat pada vibrasi tekuk pada bilangan gelombang $894 \mathrm{~cm}^{-}$ 1. Hasil ini juga serupa dengan CMC komersial (Tabel 1).

\section{KESIMPULAN}

Konsentrasi terbaik sintesis karboksimetil selulosa dari rumput gajah diperoleh pada konsentrasi asam trikloroasetat $20 \%$ dan waktu reaksi 3 jam dengan nilai DS CMC 0,839. Rendemen tertinggi sintesis karboksimetil selulosa dari rumput gajah diperoleh pada konsentrasi asam trikloroasetat 30\% dengan waktu reaksi 4 jam dan rendemen CMC yang dihasilkan $30,15 \%$.

\section{DAFTAR PUSTAKA}

Agustriono, F. R., \& Hasanah, A. N. (2016). Review Pemanfaatan Limbah sebagai 
Bahan Baku Sintesis Karboksimetil Selulosa. Farmaka, 14(3): 87-94. https://doi.org/10.24198/jf.v14i3.10788

Bidin, A. (2010). Optimasi Kondisi Reaksi Sintesis Karboksimetil Selulosa Dari Jerami Padi (Oryza sativa). [Skripsi]. Universitas Tadulako.

Elomaa, M., Asplund, T., Soininen, P., Laatikainen, R., Peltonen, S., Hyvärinen, S., \& Urtti, A. (2004). Determination of the degree of substitution of acetylated starch by hydrolysis, $1 \mathrm{H}$ NMR and TGA/IR. Carbohydrate Polymers, 57(3): 261267.

https://doi.org/10.1016/j.carbpol.2004. 05.003

Ferdiansyah, M. K., Marseno, D. W., \& Pranoto, Y. (2017). Optimasi Sintesis Karboksi Metil Selulosa (CMC) dari Pelepah Kelapa Sawit Menggunakan Response Surface Methodology (RSM). AgriTECH, 37(2): 158-164. https://doi.org/10.22146/agritech.2536 3

Lestari, P., Hidayati, T. N., Lestari, S. H. I., \& Marseno, D. W. (2013). Pengembangan Teknologi Pembuatan Biopolimer Bernilai Ekonomi Tinggi Dari Limbah Tanaman Jagung (Zea Mays) Untuk Industri Makanan: Cmc (Carboxymethylcellulose). Pekan IImiah Mahasiswa Nasional Program Kreativitas Mahasiswa - Penelitian 2013. Pekan Ilmiah Mahasiswa Nasional Program Kreativitas Mahasiswa - Penelitian 2013, Jakarta. https://www.neliti.com/id/publications/1 70681/

Martina, A., Yuli, N., \& Sutisna, M. (2002). Optimasi Beberapa Faktor Fisik Terhadap Laju Degradasi Selulosa Kayu Albasia (Parserianthes falcataria (L) Nielsen Dan Karboksimetilselulosa (CMC) Secara Enzimatik oleh Jamur,. Jurnal Natur Indonesia, 4(2): 156-163.

Melisa., Bahri, S., Nurhaeni. (2014). Optimasi Sintesis Karboksimetil Selulosa dari Tongkol Jagung Manis (Zea mays L.
Saccharata. Online Journal of Natural Science, 3(2): 70-78.

Minifie, B. (1989). Chocolate, Cocoa, and Confectionery. Van Nostrand Reinhold.

Nasution, H. I., Dewi, R. S., \& Hasibuan, P. (2016). Pembuatan Etanol Dari Rumput Gajah (Pennisetum purpureum Schumach) Menggunakan Metode Hidrolisis Asam dan fermentasi Saccharomyces cerevsiae. Jurnal Pendidikan Kimia, 8(2): 144-151. https://doi.org/10.24114/jpkim.v8i2.444 1

Nisa, D., \& Putri, W. D. R. (2014). Pemanfaatan Selulosa Dari Kulit Buah Kakao (Teobroma cacao L.) Sebagai Bahan Baku Pembuatan Cmc (Carboxymethyl Cellulose). Jurnal Pangan Dan Agroindustri, 2(3): 34-42.

Nur'ain, N., Nurhaeni, N., \& Ridhay, A. (2017). Optimasi Kondisi Reaksi Untuk Sintesis Karboksimetil Selulosa (CMC) Dari Batang Jagung (Zea mays L.). KOVALEN: Jurnal Riset Kimia, 3(2): 112-121.

Safitri, D., Rahim, E. A., Prismawiryanti, P., \& Sikanna, R. (2017). Sintesis Karboksimetil Selulosa (CMC) Dari Selulosa Kulit Durian (Durio zibethinus). KOVALEN: Jurnal Riset Kimia, 3(1): 58-68.

Saleh, A., Pakpahan, M. M. D., \& Angelina, N. (2009). Pengaruh Konsentrasi Pelarut, Temperatur Dan Waktu Pemasakan Pada Pembuatan Pulp Dari Sabut Kelapa Muda. Jurnal Teknik Kimia, 16(3): 37-38.

Sanderson, M. A., \& Adler, P. R. (2008). Perennial Forages as Second Generation Bioenergy Crops. International Journal of Molecular Sciences, $\quad$ 9(5): 768-788. https://doi.org/10.3390/ijms9050768

Sebayang, F., \& Sembiring, H. (2017). Synthesis of CMC from Palm Midrib Cellulose as Stabilizer and Thickening Agent in Food. Oriental Journal of Chemistry, 33(1): 519-530. 
Silsia, D. (2018). Characterization of Carboxymethyl Cellulose (CMC) of Palm Midrib. Jurnal Agroindustri, 8(1): 53-61.

Wagiyanto, D. (2009). Kimia Teknik. http://blog.uns.ac.id, diakses pada 19 Desember 2020.

Wijayani, A., Umma, K., \& Tjahjani, S. (2005). Karakteristik Karboksimetil Selulosa (CMC) dari Enceng Gondok (Eichornia crassipes (Mart) Solms). Universitas Negeri Surabaya. Indo. J. Chem, 5(3): 228-231.

Winarno, F. (1985). Kimia Pangan dan Gizi. Gramedia Pustaka Utama, Jakarta. 